\title{
Variation of Rainfall with Space and Time in Duhok Government
}

\author{
Dr. Waleed I. Al- Rijabo \\ Department of Physics \\ College of Education \\ Mosul University
}

\author{
Diyar A. Bleej \\ Department of Physics \\ College of Education \\ Duhok University
}

Received
$14 / 09 / 2008$
Accepted

16 / 02 / 2009

\section{الخالصة}

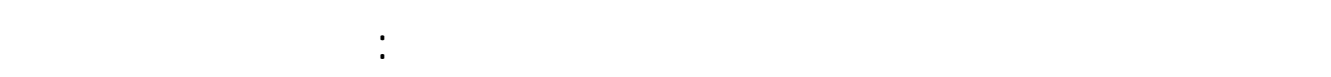

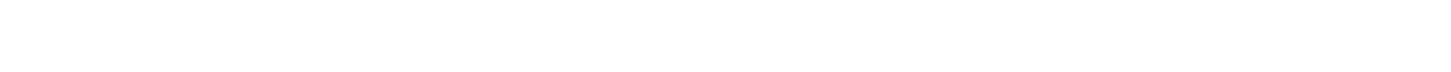
المجاري المائية ونشطلت وفعاليلت الإنسان.

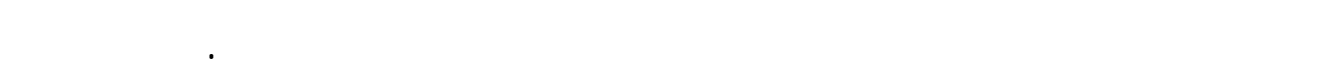

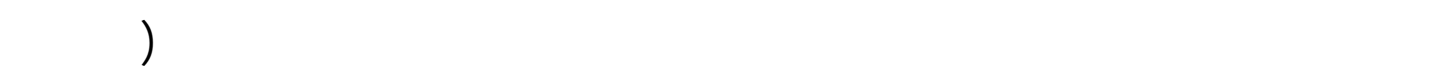
زلخو،سميل زاويتة،سربسك، عماية، عقرة).

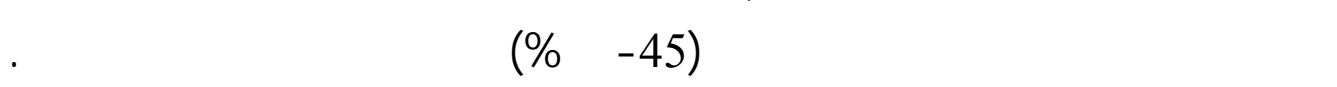

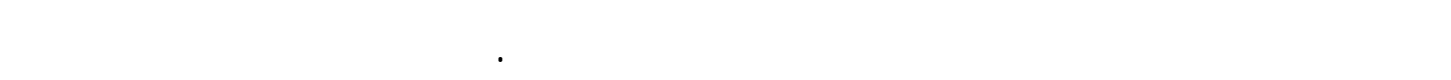

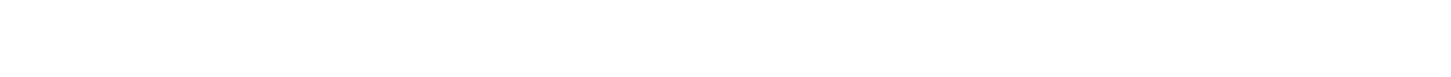
عموم محلفظة دهوك. قم إيجاد علافلت الانحدار الخطي البسط والمتعدد بين الأطار الـ ساقطة ومختل ف العناصر المنلخية.

\begin{abstract}
Rainfall analysis is important in different domains such as: agricultural planning, water resources plannings, runoff prediction, climatological studies, environmental studies, stream flow estimation and human life activities. Variation of rainfall with space and time were studied in Duhok Governorate, Mean monthly, seasonal and annual values of rainfall were found in different weather stations (Duhok, Zakho, Semel, Zawaite, Sersing, Amedy and Akre station). Winter months represent about $45-55 \%$ of the total annual rainfall. The annual variability of rainfall in all these stations are high. Isoheytal method was used to estimate the mean monthly values and mean annual values of
\end{abstract}


rainfall over Duhok Governorate. Simple and Multiple Regression Equation were found between rainfall and different meteorological elements.

\section{Introduction}

Rainfall varies with space and time at various rates, some times very rapidly. This variation is measured either at a number of points using raingauges or areally, using radar and satellites (1.2).

Rainfall being the predominant form of precipitation causing streamflow, especially the flood flow in many countries and is responsible for most runoff. In addition, vertical transport of air mass is a requirement for precipitation, so far rainfall to be formed, the atmosphere must have sufficient moisture, there must be sufficient nuclei present to aid condensation, of water vapour and the product of condensation must be good for condensation must reach the earth. $(3,4)$.

The amount, intensity and areal distribution of rainfall are essential factors in many hydrological studies $(5,6)$. Rainfall varies geographically, temporally and seasonably $(7,8)$. Regional and seasonal variations of rainfall are very important for water resources planning. Temporal variation in raifall intensity are extremely important in the raifall runoff process in urban areas (9).

Rainfall is also highly affected by the meteorological elements and elevation from sea level, so simple and multiple correlations were found between these variables $(10,11)$. This research can be considered as the first study of rainfall variation over Duhok Governorate, which is located in the northern part of iraq and lies between latitude $\left(36^{\circ}-38^{\circ} \mathrm{N}\right)$. and longitude $\left(42^{\circ}-45^{\circ} \mathrm{E}\right)$.

The studied area contains seven weather stations, (Duhok, Zakho, Semel, Zawite, Sersing, Amedy and Akre). Fig (1) shows the studied area and the locations of the weather stations.

The latitude, longtude, altitude and years of observations for the different weather stations were presented in table (1).

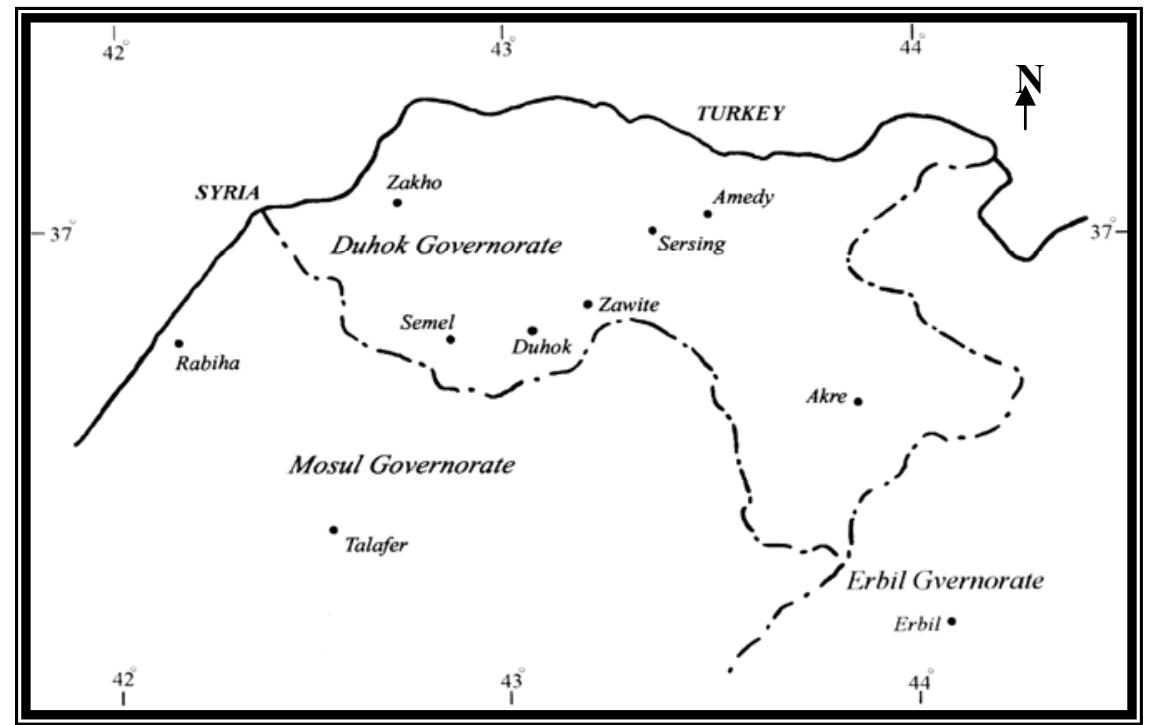

Fig. (1): the location of chosen stations for study in the study area 
Table (1): The selected weather stations in Duhok Governorate and their geographical information.

\begin{tabular}{|c|c|c|c|c|}
\hline $\begin{array}{c}\text { Weather } \\
\text { stations }\end{array}$ & $\begin{array}{c}\text { Latitude } \\
\text { (North) }\end{array}$ & $\begin{array}{c}\text { Longitude } \\
\text { (East) }\end{array}$ & $\begin{array}{c}\text { Altitude } \\
(\mathbf{m})\end{array}$ & $\begin{array}{c}\text { Years of } \\
\text { observation }\end{array}$ \\
\hline Duhok & $36^{\circ} 50^{\prime}$ & $43^{\circ} 02^{\prime}$ & 583,0 & $1980-2005$ \\
\hline Zakho & $37 \circ 08^{\prime}$ & $42^{\circ} 41^{\prime}$ & 433,8 & $1980-2005$ \\
\hline Semel & $36^{\circ} 50^{\prime}$ & $42^{\circ} 80^{\prime}$ & 870.0 & $1980-2005$ \\
\hline Zawite & $36^{\circ} 54^{\prime}$ & $43^{\circ} 09^{\prime}$ & 890.0 & $1992-2005$ \\
\hline Sersing & $37 \circ 03^{\prime}$ & $43^{\circ} 21^{\prime}$ & 1019.0 & $1992-2005$ \\
\hline Amedy & $37 \circ 05^{\prime}$ & $43^{\circ} 29^{\prime}$ & 1202.0 & $1980-2005$ \\
\hline Akre & $36^{\circ} 43^{\prime}$ & $43^{\circ} 51^{\prime}$ & 636.0 & $1993-2005$ \\
\hline
\end{tabular}

The climatic data and rianfall data are obtained from:

- Duhok weather station .

- Archives of the FAO coordianation office for Nothern Iraq.

- Iraqi Meteorological Organization.

\section{Data Analysis}

1. Raifall Data in $(\mathrm{mm})$ for the different weather stations (Duhok, Zakho, Semel, Zawaite, Sersing, Amedy and Akre) were collected and analyzed.

2. Histograms and Tables were found and explained for the mean monthly, seasonal and annual values of rainfall in all the stations present in Duhok Governorate.

3. Isohyetal method was used to estimate the mean annual values and the mean monthly values of rainfall in Duhok Governorate. This method explained in detial in ref $(3,5,9)$.

4. Correlations between Rainfall and Different Meteorological Elements in Duhok city were found.

\section{Results \& Discussion}

\section{1: Mean monthly Values of Rainfall}

Fig $(2-a, b, c, d, e, f, g, h)$ shows the variations of the mean monthly values of rainfall $(\mathrm{mm})$ for the different stations present in Duhok Governorate. During Jan. Feb. and March, the mean monthly value of rainfall at the different stations were ranged between:

(93-97) $\mathrm{mm}$ for Duhok, (83-86)mm for Semel, (100-112)mm for Zakho, (119-138)mm for Sersing, (111-157)mm for Zawaite, (108160)mm for Akre and (112-147) mm for Amedy station.

In April the highest value of rainfall was obtained in Amedy (108) $\mathrm{mm}$, while the values of other stations were ranged between (42-71) $\mathrm{mm}$. 
May and October showed the minimum values of rainfall which is ranged between (17-40) $\mathrm{mm}$ in all the stations.

November is nearly look like April. In Dec, the values of rainfall was ranged between $(83-120) \mathrm{mm}$ in all the stations.

Semel station shows always the lowest value of rainfall in the region. Amedy station shows the highest values of rainfall in March, April and Nov, while Zawaite station shows the highest values in Dec., Jan. and Feb.

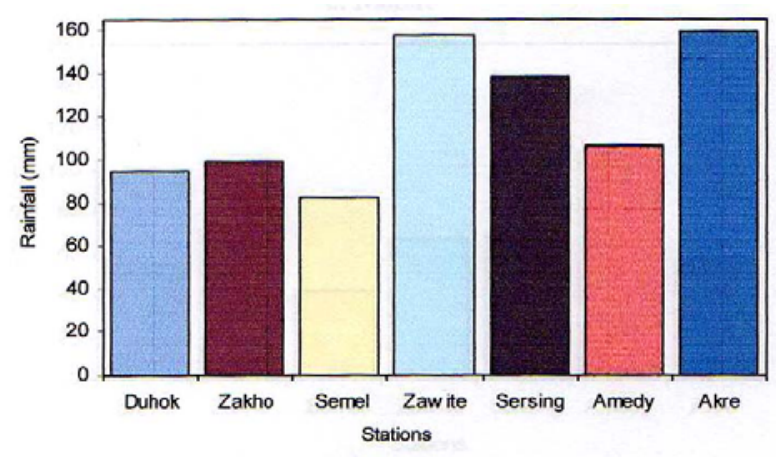

a. January
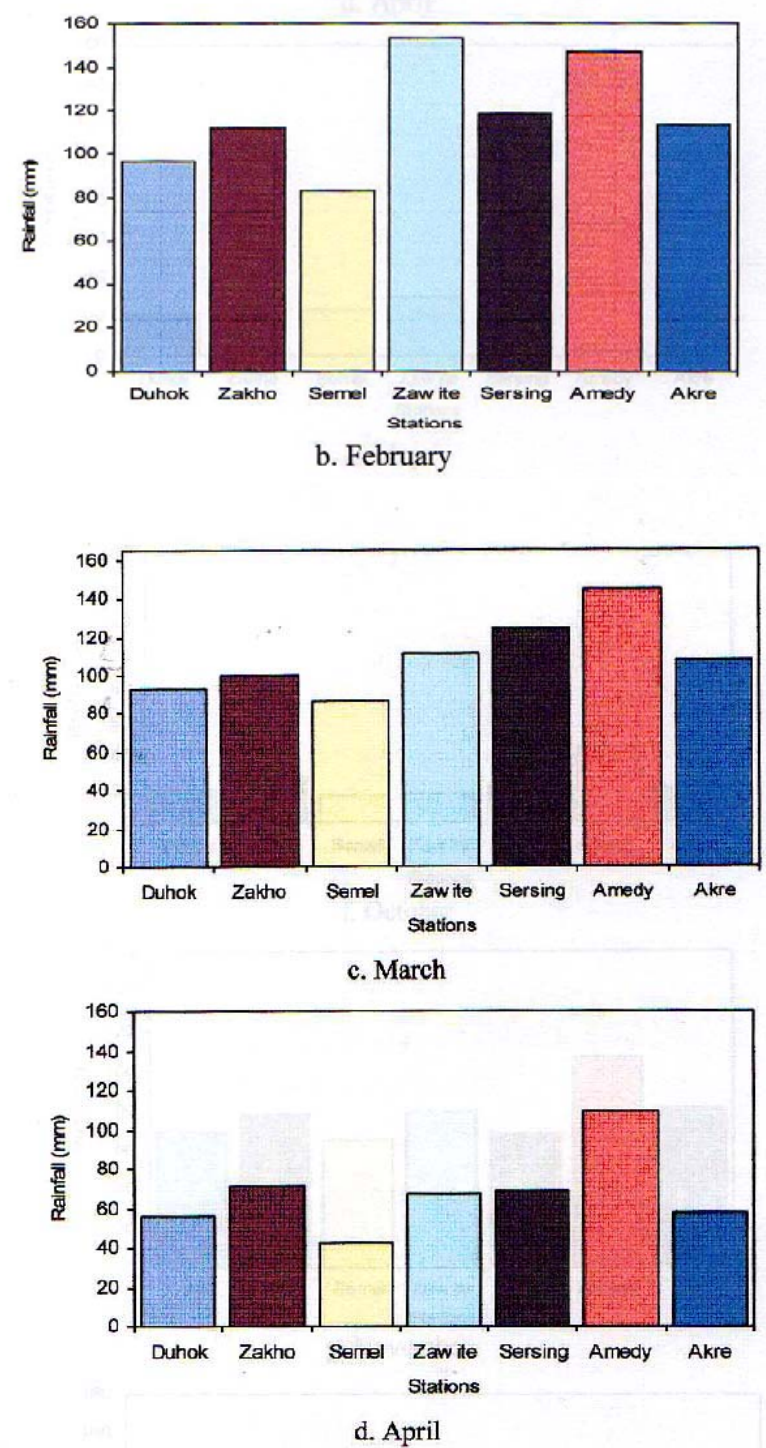


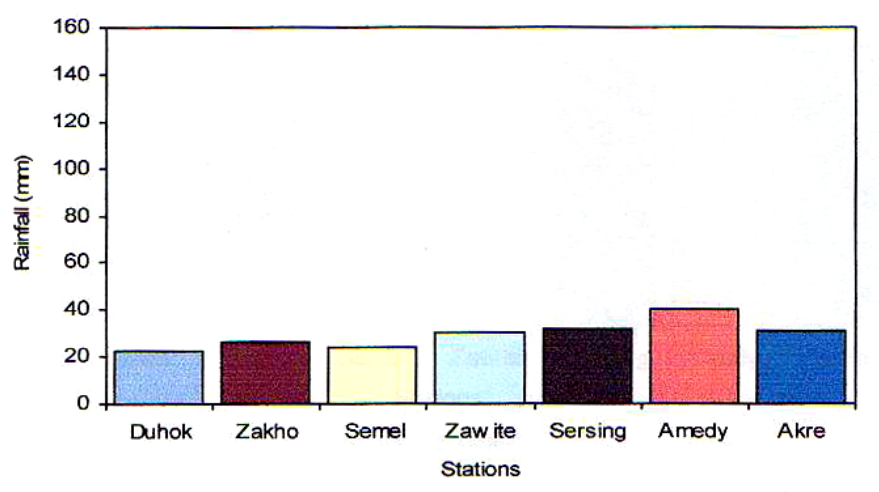

e. May

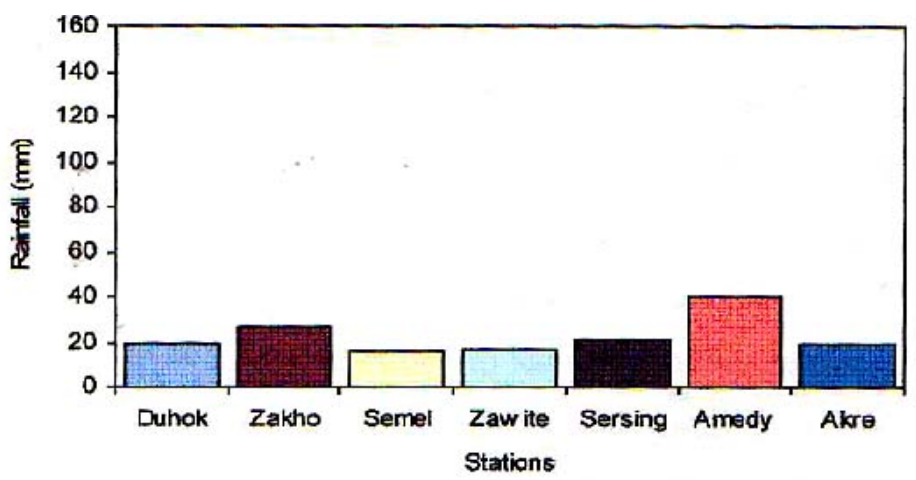

f. October

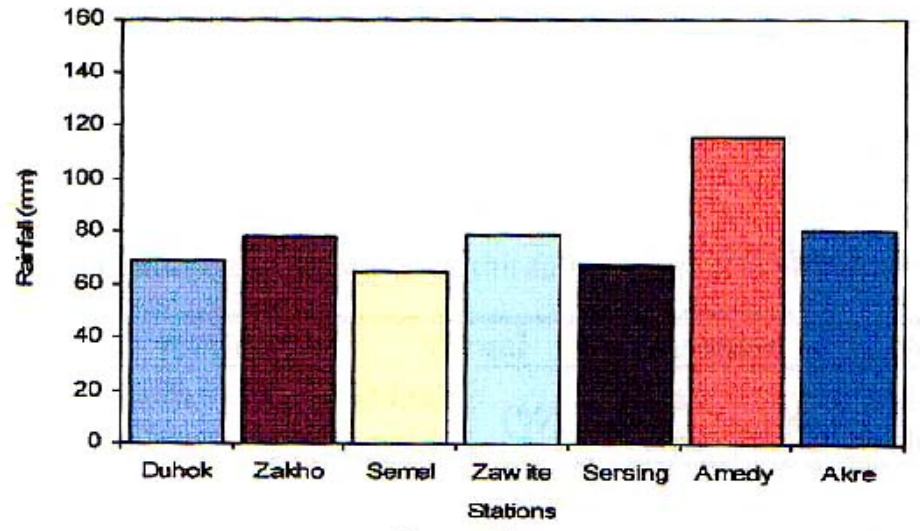

g. November

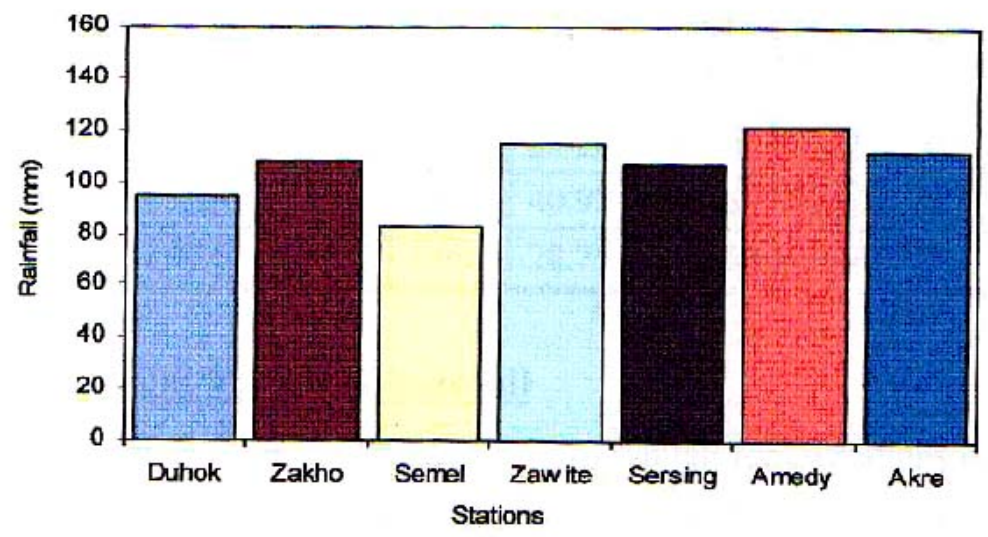

h. December

Fig (3-1, a, b, c, d, e, f, g, h) Variations of the mean monthly values of rainfall 2(mm) for all stations in Duhok Governorate 


\section{2: Mean Seasonal Values of Rainfall}

Table (2) shows the mean seasonal values of rainfall in all the stations present in Duhok Governorate.

Winter season recieves about (45-55\%) of the annual rainfall and thus it represents the wettest season of the year.

The Vernal season recieves a valuable amount of rainfall and contributes $28-35 \%$ of the annual rainfall. The Autumn season contibutes $13-21 \%$ of the annual rainfall. Summer season receive less than $0.5 \%$ of the total annual rainfall and for most of the times can be neglected.

Table (2): Mean season Value of Rainfall in ( $\mathrm{mm}$ ) for all the stations.

\begin{tabular}{|c|c|c|c|c|c|c|c|c||}
\hline \multirow{2}{*}{ Stationson } & \multicolumn{2}{|c|}{ Winter } & \multicolumn{2}{c|}{ Vernal } & \multicolumn{2}{c|}{ Autumn } & \multicolumn{2}{c|}{ Summer } \\
\cline { 2 - 10 } & $\begin{array}{l}\text { Mean } \\
\text { Value }\end{array}$ & $\mathbf{( \% )}$ & $\begin{array}{c}\text { Mean } \\
\text { Value }\end{array}$ & $\mathbf{( \% )}$ & $\begin{array}{c}\text { Mean } \\
\text { Value }\end{array}$ & $\mathbf{( \% )}$ & $\begin{array}{c}\text { Mean } \\
\text { Value }\end{array}$ & $\mathbf{( \% )}$ \\
\hline Duhok & 285.9 & 52.18 & 172.4 & 31.46 & 88.8 & 16.21 & 0.8 & 0.15 \\
\hline Zakho & 319.4 & 51 & 198.6 & 31.71 & 105.4 & 16.83 & 2.9 & 0.46 \\
\hline Semel & 248.7 & 51.63 & 152.3 & 31.62 & 80.4 & 16.69 & 0.3 & 0.06 \\
\hline Zawite & 425.6 & 56.81 & 207.9 & 27.75 & 113.9 & 15.21 & 1.7 & 0.23 \\
\hline Sersink & 364.5 & 53.73 & 224.4 & 33.08 & 89.2 & 13.15 & 0.3 & 0.04 \\
\hline Amedy & 380 & 45.5 & 292 & 35 & 159.3 & 19 & 4.1 & 0.5 \\
\hline Akre & 384.6 & 56.38 & 196.1 & 28.75 & 101.2 & 14.83 & 0.3 & 0.04 \\
\hline
\end{tabular}

\section{3: Mean Annual Values of Rainfall}

Fig (3) shows mean annual values of rainfall for all stations in Duhok Governorate, which can be arragned from the heighest values to the lowest values as: Amedy $835 \mathrm{~mm}$, Zawaite: $749 \mathrm{~mm}$, Akre: $682 \mathrm{~mm}$, Sersing: $678 \mathrm{~mm}$, Zakho: $626 \mathrm{~mm}$, Duhok: $547 \mathrm{~mm}$ and Semel: $481 \mathrm{~mm}$.

The topography, atmospheric depression and the nature of air masses blowing from the surrounding areas play an important role in the variation of the annual rainfall in these locations.

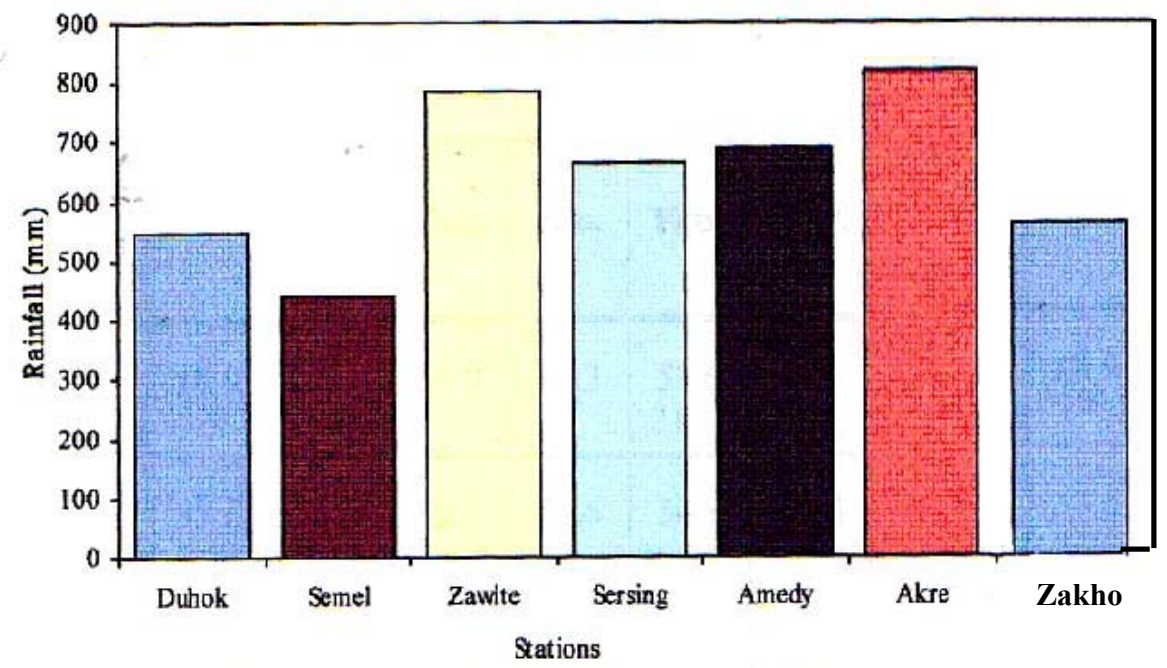

Fig. (3) The mean annual rainfall for all stations 
Table (3) shows the mean, maximum and minimum values of the annual rainfall during the period of the records.

Standard Deviation (SD) and coefficient of variation (CV) of the annual values of rainfall were also shown in this table.

Table (3): Information about the annual values of rainfall for the selected station.

\begin{tabular}{|c|c|c|c|c|c|c|c|}
\hline Stations & $\begin{array}{c}\text { Mean } \\
(\mathbf{m m})\end{array}$ & $\begin{array}{c}\text { Max. } \\
\text { Raifull } \\
(\mathbf{m m})\end{array}$ & Year & $\begin{array}{c}\text { Min. } \\
\text { Raifull } \\
(\mathbf{m m})\end{array}$ & Year & $\begin{array}{c}\text { SD } \\
(\mathbf{m m})\end{array}$ & $\mathbf{C v}$ \% \\
\hline Duhok & 546.5 & 909.70 & 1994 & 284.30 & 1999 & 166.7 & 30.7 \\
\hline Zakho & 579.3 & 943.90 & 1988 & 352.00 & 1999 & 205.9 & 35.5 \\
\hline Semel & 437.1 & 732.50 & 1988 & 189.40 & 1999 & 174.7 & 40.0 \\
\hline Zawite & 785.6 & 1266.50 & 1992 & 387.50 & 1999 & 761.6 & 91.5 \\
\hline Sersink & 663.7 & 1109.30 & 2004 & 234.30 & 1995 & 347.8 & 52.4 \\
\hline Amedy & 835 & 1086.60 & 1994 & 367.00 & 1999 & 196.8 & 28.3 \\
\hline Akre & 680.4 & 1105.80 & 1994 & 329.80 & 1999 & 203.3 & 29.9 \\
\hline
\end{tabular}

\section{4: Study of the Mean Areal Rainfall over Duhok Governorate}

The main hydromteorological problem related to the areal variation of rainfall is the estimation of rainfall over a given period of time. Isohyetal method was used to estimate the mean areal rainfall over Duhok Governorate.

Fig (4, a, b, c, d, e, f, g, h) show the mean monthly values of rainfall over Duhok Governorate during the months (Jan, Feb, Mar. Apr. may. Oct. Nov and December).

From the figure we obtain the mean monthly value of rainfall over Duhok Governorate which are $(100,104,104,66,31,26,82,103) \mathrm{mm}$ for the months Jan., Feb., March, April, May, Oct., Nov. and Dec. respectively.

Fig (5) shows that the mean annual rainfall over Duhok Governorate was $621 \mathrm{~mm}$.

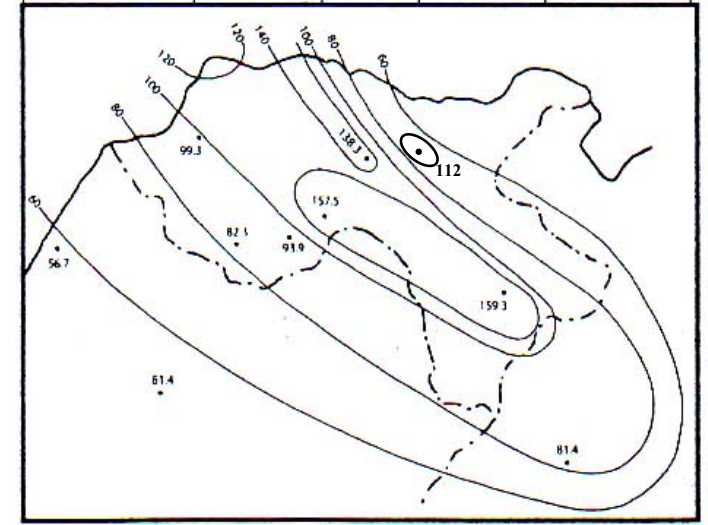

a. January month

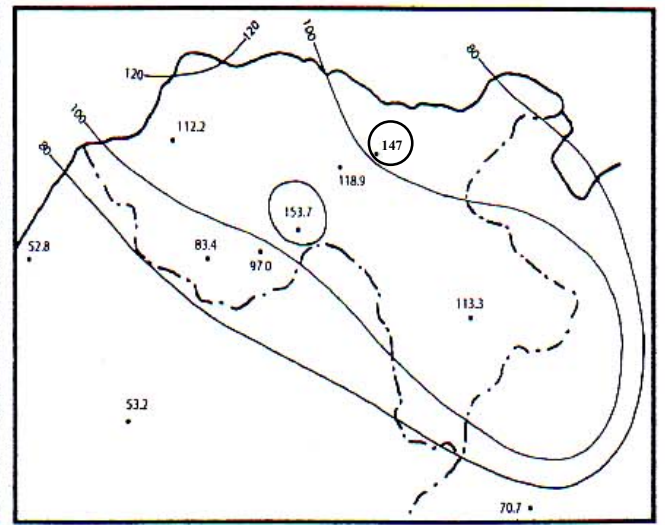

b. February month 


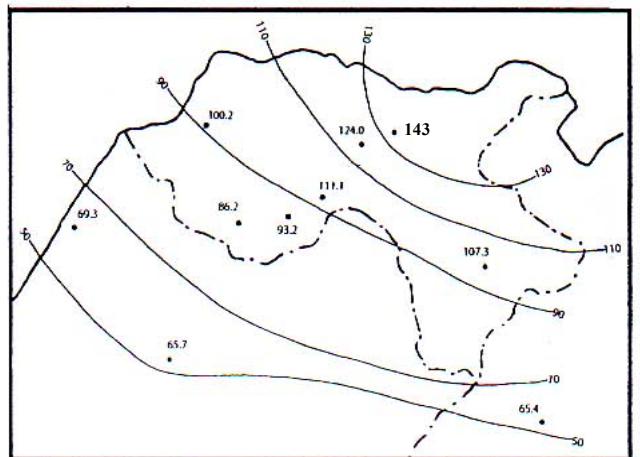

c. March month

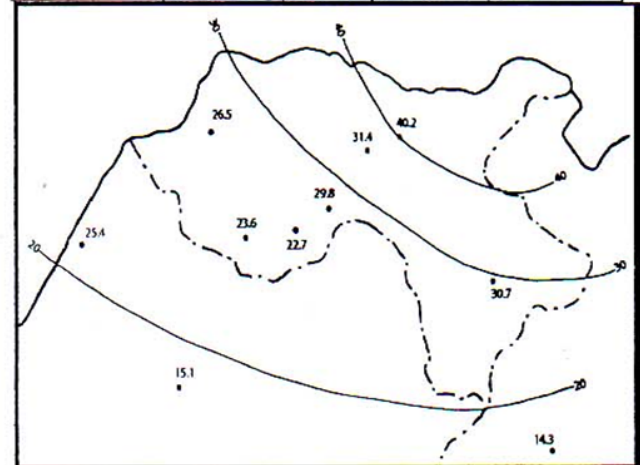

e. May month

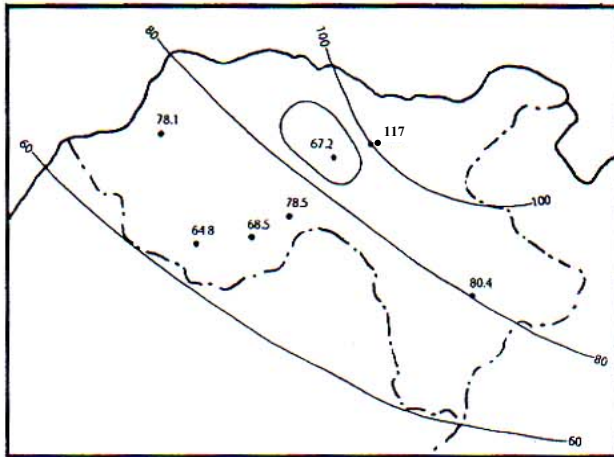

g. November month

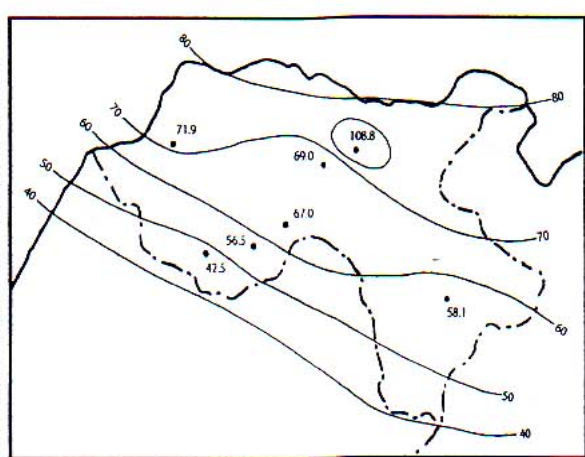

d. April month

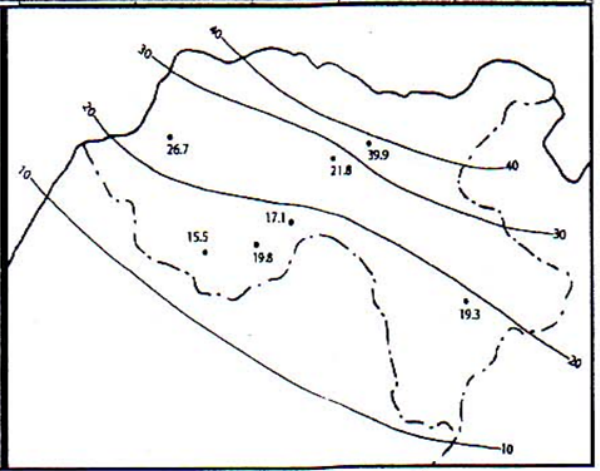

f. October month

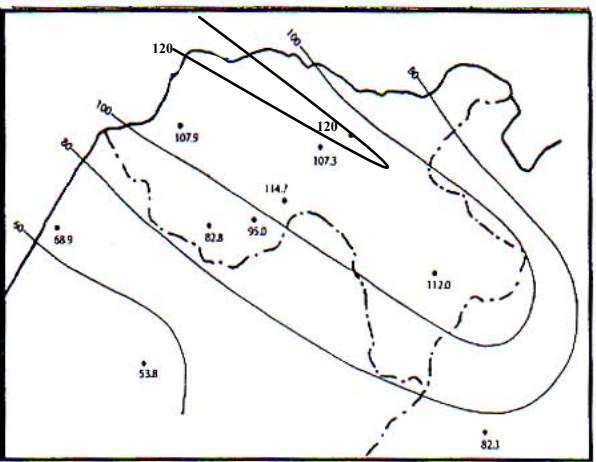

h. December month

Fig (4- a, b, c, d, e, f, g, h) : The Isohyetal method for estimating mean monthly Valus of rainfall over Duhok Governorate.

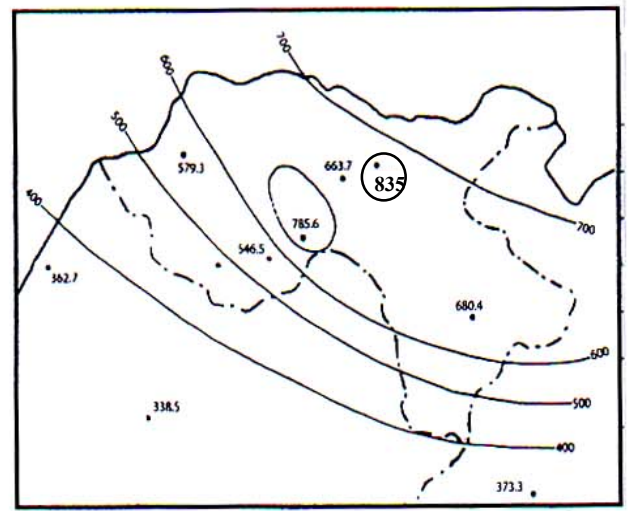

Fig ( 5 ) The Isohyetals method for estimating mean annual value of rainfall over Duhok governorate 


\section{Correlations between Rainfall and Different Meteorological} Elements in Duhok City.

Fig. (6) shows a highly negative correlation between Rainfall and Temperature in Duhok city. The value of $\left(\mathrm{R}^{2}\right)$ was $(0.95)$.

This correlation is normal because high temperature lead to evaporation and low temperature lead to condensation.

Fig. (7) shows a highly positive correlation between Rainfall and Relative Humidity in Duhok city. $\left(\mathrm{R}^{2}\right)$ was equal to $(0.94)$. it is clear that the atmospheric humidity is one of the principal factors for condensation and formation of water droplets and hence rainfall.

Fig. (8) shows clearly a highly negative correlation between rainfall and evaporation in Duhok city, where $\left(\mathrm{R}^{2}\right)$ was $(0.89)$.

Fig. (9) shows a week negative correlation between rainfall and wind speed in Duhok city. The value or $\left(\mathrm{R}^{2}\right)$ was $(0.51)$.

Fig. (10) shows a week positive correlation between rainfall and Atmospheric pressure in Duhok city. The value of $\left(\mathrm{R}^{2}\right)$ obtained was (0.59).

Multiple correlation between rainfall and all the other meteorological elements was found in Duhok city. This correlation was:

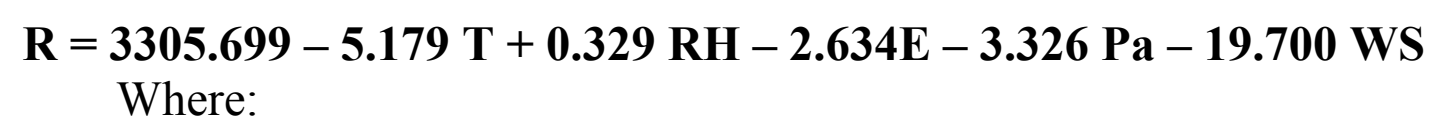

$\mathrm{R}=$ rainfall $(\mathrm{mm}), \mathrm{T}=$ temperature $\left(\mathrm{C}^{\circ}\right), \quad \mathrm{RH}=$ relative humidity $(\%)$ $\mathrm{E}=$ evaporation $(\mathrm{mm}) \quad \mathrm{Pa}=$ atm. Pressure $(\mathrm{mb}) \quad \mathrm{WS}=$ wind speed $(\mathrm{m} / \mathrm{s})$

The $\left(\mathrm{R}^{2}\right)$ of this multiple correlation was $(0.99)$.

These correlation was very important for some climatological and hydrological estimation.

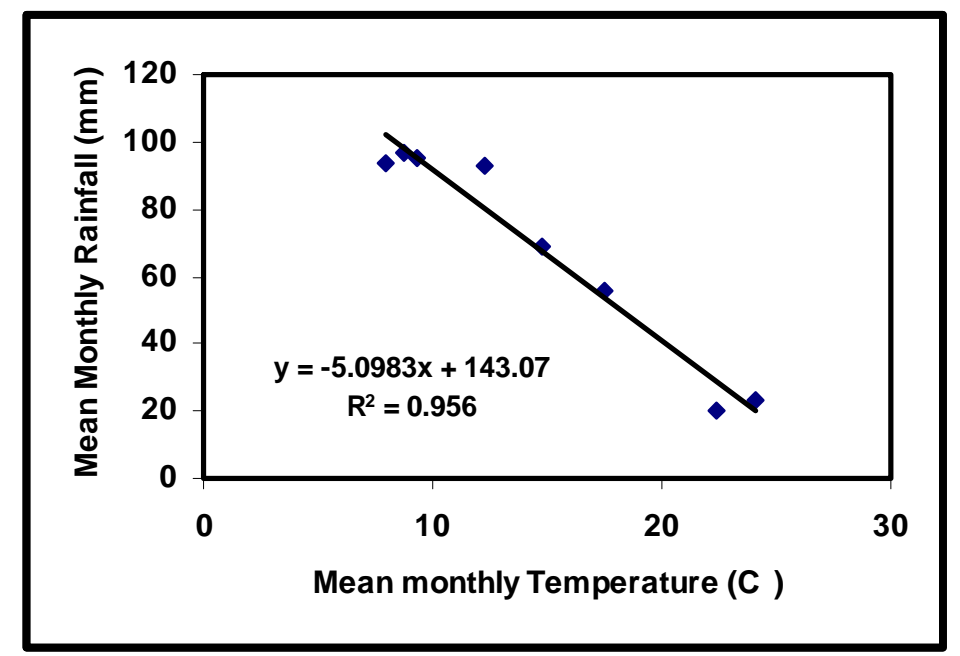

Fig (6): Correlation between Rainfall and Temperature in Duhok City 


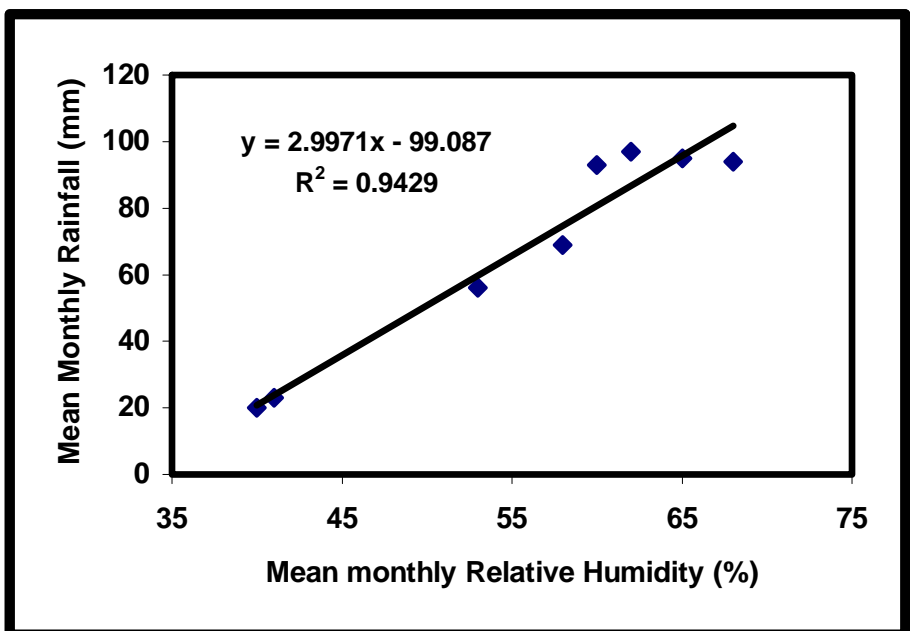

Fig (7): Correlation between Rainfall and Relative Humidity in Duhok City

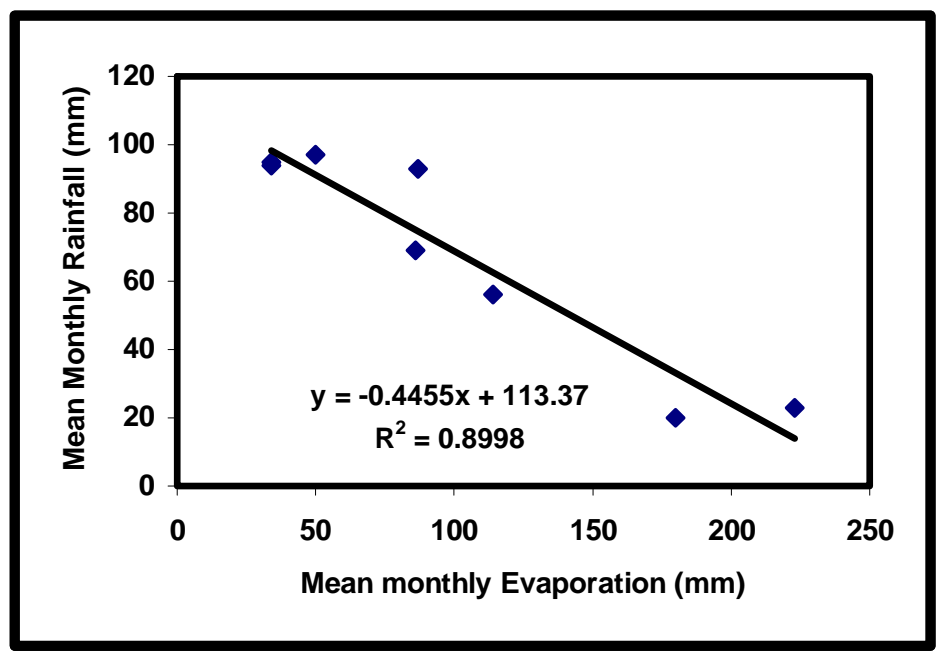

Fig (8): Correlation between Rainfall and Evaporation in Duhok City

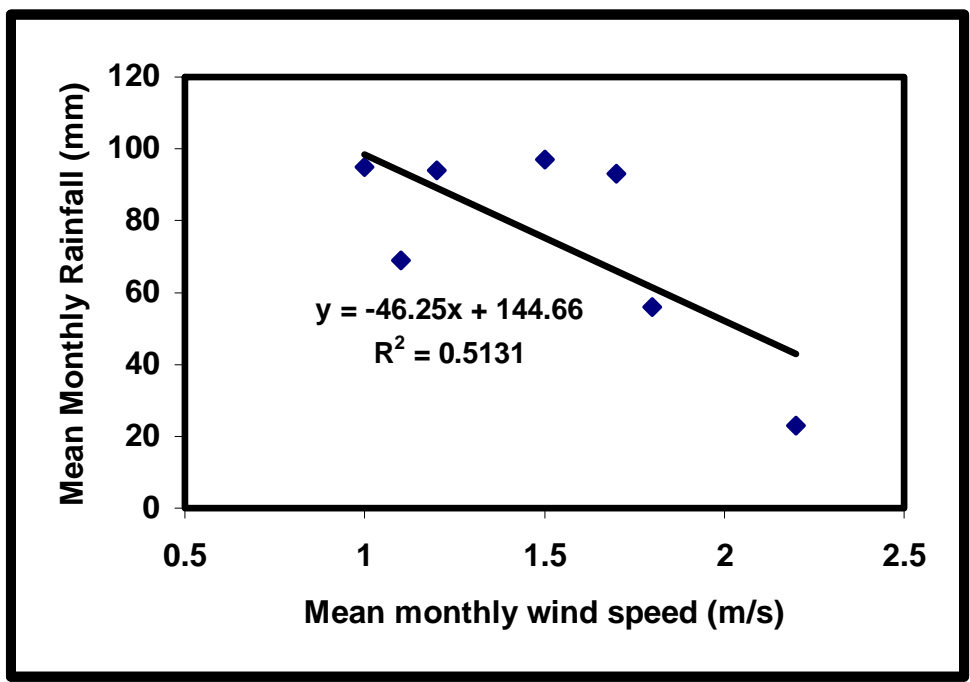

Fig (9): Correlation between Rainfall and wind speed in Duhok City 


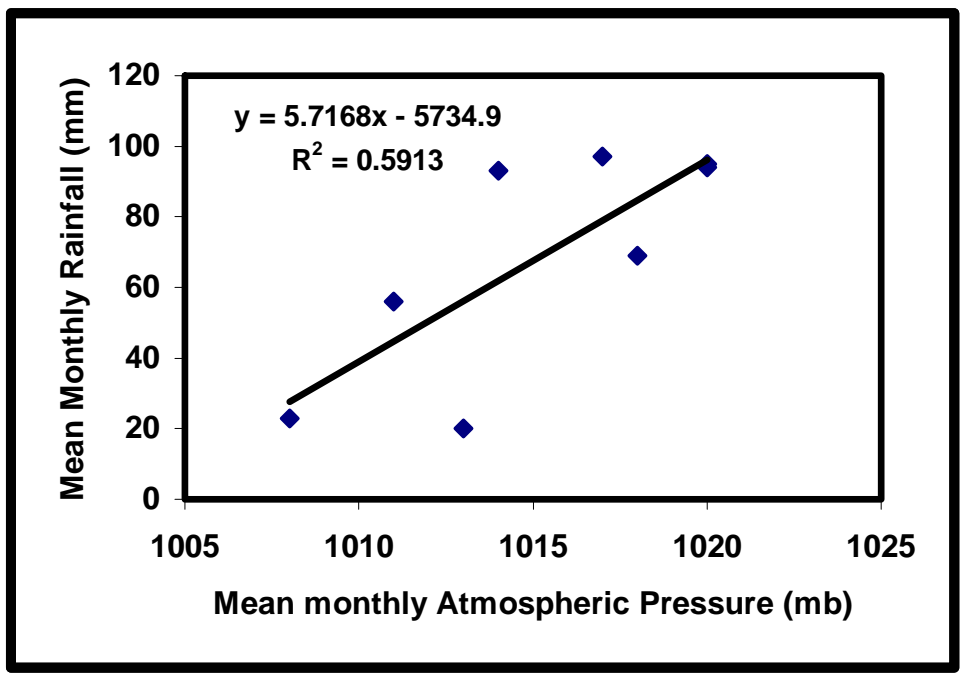

Fig (10): Correlation between Rainfall and Atmospheric Pressure in Duhok City

\section{Conclusions}

1. The maximum monthly values of rainfall was found in Amedy and in Semel station.

2. Winter months recieves about $45-55 \%$ of the annual rainfall and thus it represents the wettest season of the year.

3. The mean annual rainfall of the different stations can be arranged as: Zawaite:749mm, Amedy:688mm, Akre:682mm, Sersing:678mm, Zakho: $626 \mathrm{~mm}$, Duhok: $547 \mathrm{~mm}$ and Semel 481mm.

4. The mean monthly values of rainfall over Duhok Government aculated by Isohyetal method gives the values: 100, 105, 105, 66, 31, 26, 82 and $103 \mathrm{~mm}$ for the months Jan. Feb. mar. Apr. May. Oct. Nov. and Dec.

5. Simple linear regression equations between rainfall and other meteorological elements in Duhok city were found. $\left(\mathrm{R}^{2}\right)$ obtained between Rainfall and Temperature, Relative Humidity, Evaporation, Wind Speed and Atmospheric Pressure were (0.95, 0.94, 0.89, 0.51, 0.59 )

6. Multiple Correlation between Rainfall and all other Meteorological Elements for Duhok city was

$$
R=3305.699-5.179 T+0.329 R H-2.634 E-3.326 \mathrm{~Pa}-19.700 \mathrm{WS}
$$




\section{References}

1. S. L. Solomon and I. Cordery, (1984), "Hydrometeorology", WMO No. 365, Vol.2, Part5.

2. Legates, D. R. and Willmott, (1990), "Mean seasonal and spatial variability in guage- corrected global precipition", Int. J. Climatol. Vol. 10, pp (111-127).

3. Subramanya, K., (1984), "Engineering Hydrology". Tata Mc Graw Hill Publishing Company.

4. Danielson, E. W., levin, J. and Abrams E., (2003), "Meteorology", second edition. Mc Graw Hill Publishing companies Inc.

5. Mutreja, K. N., (1990), "Applied Hydrology", Tata Mc Graw Hill Publishing Company Limited.

6. Juny, H. S., Gyu, H. L. and Jai, H. o., (2001), "Interpretation of the transient variation of precipitation amount in Seoul", American Meteo. Society, Vol. 14, No.13.

7. Thiam, EI. And Singh, v.p., (2002), "Space-time-frequency analysis of rainfall, Runoff and temperature in Casamance River Basin, Southern senegal, West Africa", university of Louisiana, Vol. 28, No.3, pp (259-292).

8. Ovuka, Mira and Seven, (2002), "Rainfall variability in Murany a District, Kenya: Meteorology data farmers precipitation", Gotebory university, Gotebory-Sweden. 82, A (1), pp (107 - 119) .

9. Bruce, J. P. and Clark, R. H., (1980). "Introduction to Hydrometeorology", Pergamon Press Ltd.

10. Anwer, H. D., (2004), "study of some techniques for processing Rainfall Time Series in the North part of Iraq.", Msc Thesis, College of Engineering, university of Mosul.

11. Diyar, A. B., (2007). "Evaluation of precipitation in Duhok Government", Msc. Thesis. College of science of Education, university of Duhok. 